\title{
Recombinase polymerase amplification assay combined with a lateral flow dipstick for rapid detection of Tetracapsuloides bryosalmonae, the causative agent of proliferative kidney disease in salmonids
}

\author{
Hatem Soliman*, Gokhlesh Kumar and Mansour El-Matbouli
}

\begin{abstract}
Background: The myxozoan Tetracapsuloides bryosalmonae, the causative agent of proliferative kidney disease (PKD), is responsible for considerable losses in farmed and wild fish populations in Europe and North America. Recently, $T$. bryosalmonae was detected in many European countries, and strategy to control the disease in the wild and farmed fish population is yet to be developed. Recombinase polymerase amplification (RPA) is a novel isothermal nucleic acid amplification technology that does not require any thermal cycling, and lateral flow dipstick (LFD) is a rapid, costeffective, and easy-to-handle assay that enables stable detection.

Results: In this study, we developed and optimized a rapid and sensitive RPA assay combined with an LFD for the detection of T. bryosalmonae. The PKD-RPA assay was specific to T. bryosalmonae, as no cross-reaction or false positive signals were observed with any of the other tested DNAs. The developed PKD-RPA assay was ten times more sensitive than an existing diagnostic polymerase chain reaction (PCR) assay for this parasite. The estimated time to perform PKD-RPA assay is $25 \mathrm{~min}$ compared to $4 \mathrm{~h}$ for PKD-PCR assay.

Conclusions: A novel PKD-RPA assay for the detection of T. bryosalmonae was developed. The assay offers considerable advantages including speed, sensitivity, specificity and visual detection. Applying the PKD-RPA assay combined with an LFD enhances the surveillance and early detection of $T$. bryosalmonae in salmonids.
\end{abstract}

Keywords: Diagnosis, PKD, Isothermal amplification, RPA, Trout

\section{Background}

Proliferative kidney disease (PKD), an emerging parasitic disease, is threatening both farmed and wild salmonid populations in North America and Europe [1, 2]. The malacosporean parasite Tetracapsuloides bryosalmonae is the causative agent of PKD in salmonids [3]. Tetracapsuloides bryosalmonae uses bryozoan Fredericella sultana as invertebrate hosts and salmonids as vertebrate hosts to complete its life-cycle [4-6]. The water-borne T. bryosalmonae spores, which are released from infected bryozoan colonies, enter through the gill epithelium $[7,8]$ and reach

\footnotetext{
* Correspondence: hatem.soliman@vetmeduni.ac.at

Clinical Division of Fish Medicine, University of Veterinary Medicine, Veterinärplatz 1, 1210 Vienna, Austria
}

the kidney through the vascular system [9], where further propagation and differentiation occurs. Mature spores are excreted in urine to infect the bryozoan host $[4,5]$. Water temperature plays a crucial role in the development and pathology of PKD in salmonid fish, as a direct positive relationship exists between the severity of clinical signs, as well as associated mortality, and increasing water temperature $[1,10-12]$. The clinical symptoms of PKD in fish are exophthalmia, enlarged kidney, splenomegaly, darkened body, pale gills and abdominal distension [1]. The mortality rates vary and can reach $100 \%$ when secondary infections are involved [13-15]. In some European rivers, PKD is widely distributed and assumed to be responsible for mortalities in wild salmonid populations, particularly brown 
trout Salmo trutta and Atlantic salmon Salmo salar [1621]. Multiple dispersal routes likely contribute to distribution of PKD parasite such as vertical transmission of $T$. bryosalmonae in statoblasts $[22,23]$ and escaping of migrating zooids from deteriorating bryozoan colonies [24]. The molecular analysis of T. bryosalmonae ITS1 strains has revealed two main lineages, originating from Europe and North America [25]. Traditionally, a presumptive diagnosis of PKD was made by the detection of the T. bryosalmonae spores in the kidney using wet mounts, Giemsastained or lectin-stained kidney imprints [26-28]. The confirmatory diagnosis was based on the histological examination of tissue sections stained with hematoxylin and eosin [29-31]. In addition, specific monoclonal antibodies were used for the detection of T. bryosalmonae in the infected fish kidney [32-34]. Subsequently, DNA-based detection assays, such as in situ hybridization, polymerase chain reaction (PCR), real-time PCR and loop-mediated isothermal amplification assays, were developed for specific and sensitive detection of T. bryosalmonae [35-43]. Despite its advantages, PCR has intrinsic disadvantages, such as timeconsuming, expensive instruments, and complicated procedures for the detection of amplified products [44, 45].

Recombinase polymerase amplification (RPA) is a novel isothermal nucleic acid amplification technology that does not require any thermal cycling, as the amplification reaction is performed at a constant low temperature [46]. Notably, RPA utilizes an enzymatic mixture of polymerase and DNA recombination proteins and can be performed using a simple shaking incubator $[46,47]$. Recombinase enzyme binds to the primers to form a complex that promotes primers to anneal to its homologous sequence in a double-stranded DNA (dsDNA) template; the DNA polymerase then displaces the dsDNA strands and elongates the primer, resulting in an exponential amplification of the target [46, 48-50]. By including a specific probe into the RPA reaction solution, the amplification products can be visualized by a lateral flow dipstick (LFD), which is more advantageous than the other detection methods because of its rapidity, low-cost, ease of use and long-term stability [51, 52].

This study aimed to use RPA assay for isothermally amplifying T. bryosalmonae DNA from T. bryosalmonae- infected fish, and for detecting amplified products using LFD. The sensitivity and reliability of this detection method were assessed and compared with those of conventional diagnostic PCR.

\section{Methods}

\section{Sample collection and DNA extraction}

Specific pathogen-free (SPF) and T. bryosalmonae-infected $F$. sultana colonies were maintained in a laboratory culture system following methods of Kumar et al. [53]. Approximately 35 zooids were collected from SPF F. sultana colonies and subjected to DNA extraction to be used as a negative control. T. bryosalmonae mature spore sacs $(n=40)$ were collected from infected $F$. sultana colonies and subjected to DNA extraction to be used as a positive control. Kidney tissues from both SPF and T. bryosalmonae-infected brown trout that were sampled in our previous study [54] with ethical permission (GZ 68.205/0247II/3b/2011) were subjected to DNA extraction. All DNA extractions were performed using DNeasy blood and tissue kit (Qiagen, Hilden, Germany) according to the manufacturer's instructions. DNA concentrations were measured using NanoDrop 2000 spectrophotometer (Thermo Fisher Scientific, Vienna, Austria) and then stored at $-20{ }^{\circ} \mathrm{C}$ until use.

\section{PKD-RPA primers and probe design}

The primers and probe for PKD-RPA assay (Table 1) were designed to amplify a $141 \mathrm{bp}$ segment of internal transcribed spacer 1 (ITS1) sequence of the rRNA gene of $T$. bryosalmonae (GenBank accession number JQ424926). All the available T. bryosalmonae ITS1 sequences from the National Center for Biotechnology Information (NCBI) database were aligned, and a highly conserved region was selected and used for designing the PKD-RPA primers and probe according to the TwistDX (TwistDx Ltd., Cambridge, UK) guidelines. The forward primer (PKD-RPA_F) was a normal primer (unlabeled), and the reverse primer (PKD-RPA_R) was labeled with digoxigenin at the $5^{\prime}$ end. The probe (PKD-RPA_P) was labeled with 6-carboxyfluorescein (FAM) and a polymerase extension blocking group (C3-

Table 1 The oligonucleotides used in this study

\begin{tabular}{|c|c|c|c|c|c|c|}
\hline Primer name & Primer sequence $\left(5^{\prime}-3^{\prime}\right)$ & Genome position & Primer length $(\mathrm{bp})$ & GenBank ID & Method & Reference \\
\hline PKD-RPA_F & TAATACGGATGTGGGTTAGTGGAAACTGGG & $48-77$ & 30 & JQ424926 & RPA & This study \\
\hline PKD-RPA_R & $\begin{array}{l}\text { Digoxigenin-CGTGAATCAGACCAAATATCTT } \\
\text { CAAGATGACAAG }\end{array}$ & $155-188$ & 34 & & & \\
\hline PKD-RPA_P & $\begin{array}{l}\text { FAM-GGAGTGGGAAGATAATACGTAAACGTGCATT } \\
\text { ZGCCAAGTATTAAATAG-(C3spacer) }\end{array}$ & $106-153$ & 48 & & & \\
\hline PKX 5 F & CCTATTCAATTGAGTAGGAGA & $463-483$ & 21 & U70623 & PCR & [36] \\
\hline PKX $6 R$ & GGACCTTACTCGTTTCCGACC & $877-897$ & 21 & & & \\
\hline
\end{tabular}


spacer) at its both $5^{\prime}$ and $3^{\prime}$ ends, respectively. In addition, the probe was modified internally by replacing one nucleotide with tetrahydrofuran (THF; also known as dSpacer). The specificity of the primers and probe was assessed in silico using the basic local alignment search tool (BLAST) against the NCBI nucleotide database to ensure that no homology exists with other organism sequences. The primers and probe were synthesized by Eurofins Genomics (Ebersberg, Germany).

\section{PKD-RPA assay}

The PKD-RPA reaction was performed using a TwistAmp nfo kit (TwistDx Ltd.). Various reaction temperatures, incubation times, and primer concentrations were tested to determine the optimal reaction conditions. The PKD-RPA reaction was carried out in a total volume of $50 \mu \mathrm{l}$ containing $3 \mu \mathrm{l}$ PKD-RPA_F primer $(10 \mu \mathrm{M}), 3 \mu \mathrm{l}$ PKD-RPA_R primer $(10 \mu \mathrm{M}), 1 \mu \mathrm{l}$ PKDRPA_P probe $(10 \mu \mathrm{M}), 29.5 \mu \mathrm{l}$ rehydration buffer, $11 \mu \mathrm{l}$ of both DNA template and nuclease-free water, and finally, one enzyme pellet from the kit was added to each reaction tube. To start the reaction, $2.5 \mu \mathrm{l}$ of $280 \mathrm{mM}$ magnesium acetate was added and then the tubes were incubated at $38{ }^{\circ} \mathrm{C}$ for $4 \mathrm{~min}$. The reaction mixtures were then mixed briefly and re-incubated at the same temperature for another 16 min. PKD-RPA amplification products were detected by the visual inspection of a colorimetric signal on a nucleic acid LFD (HybriDetect 2T; Milenia Biotec, Giessen, Germany). PKD-RPA amplification products $(2 \mu \mathrm{l})$ were mixed with $98 \mu \mathrm{l}$ of assay buffer [ $1 \times$ phosphate buffered saline (PBS), $0.1 \%$ Tween 20; PBS-T]. Subsequently, $10 \mu$ lof diluted RPA product was pipette directly into the sample application area of the LFD, which was then placed in $200 \mu \mathrm{l}$ PBS-T buffer for $5 \mathrm{~min}$ at room temperature. When the test and control lines were simultaneously visible, it was considered positive. In addition, if only the control line was visible, it was considered negative. The control line confirmed that the LFD was working correctly. All tests were performed under the same conditions in triplicate.

\section{Specificity of the PKD-RPA assay}

The PKD-RPA assay was evaluated by cross-reaction tests using a range of DNA templates, including those from Buddenbrockia plumatellae (our own sample that was confirmed with PCR and sequencing), Myxobolus cerebralis, T. bryosalmonae, SPF F. sultana, T. bryosalmonae-infected F. sultana, and kidney tissues from SPF and T. bryosalmonae-infected brown trout. All these templates were tested in triplicate under the optimal conditions determined for PKD-RPA assay.

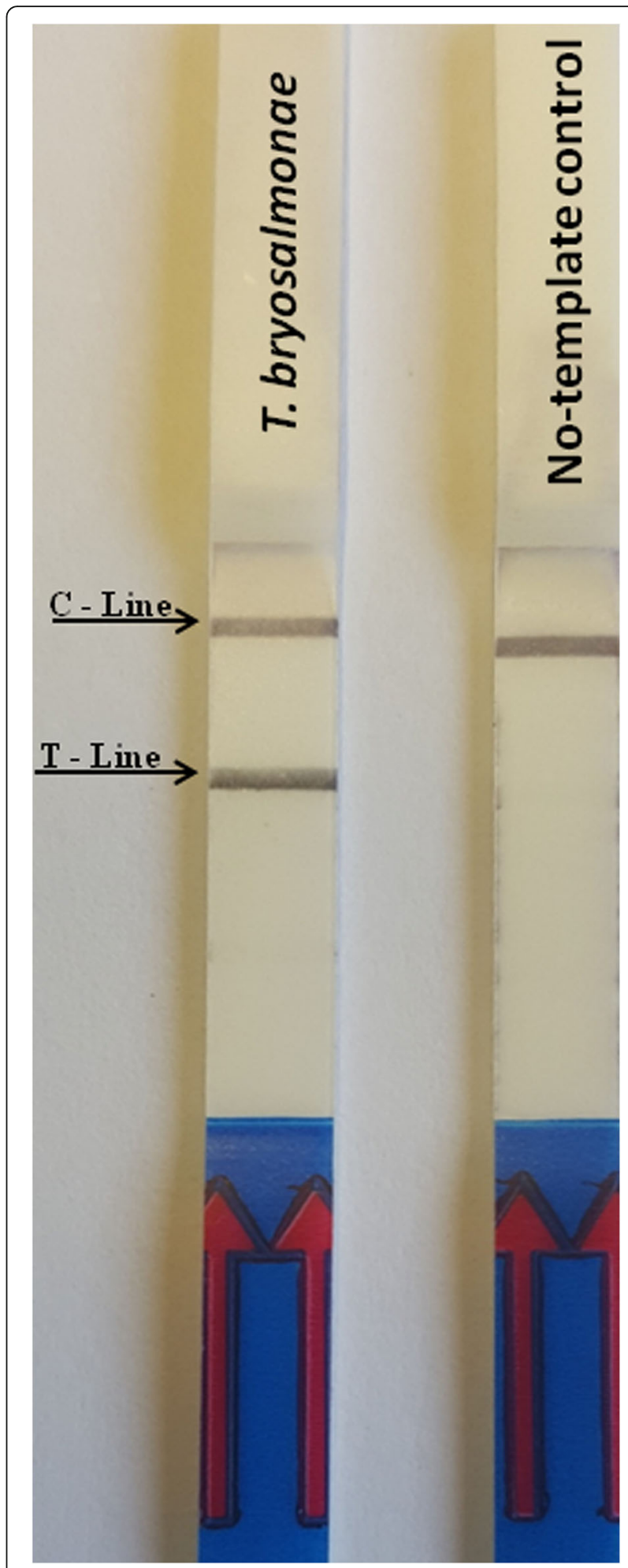

Fig. 1 PKD-RPA assay. The color signals on the lateral flow dipstick (LFD), indicating the amplification of Tetracapsuloides bryosalmonae DNA using specific recombinase polymerase amplification (RPA) primers and probes. C-line: control signal, which indicates that the LFD functioned correctly; T-line: location of the signal of amplified $T$. bryosalmonae DNA 


\section{Sensitivity of the PKD-RPA assay}

The lower detection limit of the PKD-RPA assay was determined using 10-fold serial dilutions of DNA (10 ng) from pure T. bryosalmonae sacs with and without prior mixing with DNA (100 ng) from SPF brown trout kidney. The detection limit of PKD-RPA assay was compared with that of commonly used PCR assay for the detection of T. bryosalmonae DNA developed by Kent et al. [36]. All the reactions were performed in triplicate according to the determined optimal conditions for PKDRPA and PCR assays. The detection limit was defined as the lowest concentration to test positive in the triplicate assays.

\section{Applicability of the PKD-RPA assay}

After optimization of the reaction conditions for the PKD-RPA assay, the feasibility of using this assay for the detection of T. bryosalmonae DNA in clinical samples was evaluated by testing retrospective DNA samples that were extracted from 86 clinical fish samples (brown trout and rainbow trout), that had been submitted to our clinic for PKD diagnosis. The results of the PKD-
RPA assay were compared with those of the commonly used diagnostic PCR assay [36].

\section{Results \\ Optimization of the PKD-RPA assay}

The PKD-RPA assay functioned at a wide range of temperatures. No differences in amplification were observed when the PKD-RPA assay was performed between $36{ }^{\circ} \mathrm{C}$ and $46{ }^{\circ} \mathrm{C}$. However, no amplification signals were detected when the reaction was performed at room temperature or $50{ }^{\circ} \mathrm{C}$. The evaluation of the PKD-RPA amplification time revealed that obvious test bands could be observed on the LFD when the reaction mixture was incubated for 10, 15, 20, 25 and $30 \mathrm{~min}$; however, no signal was detected at $5 \mathrm{~min}$ (data not shown). Considering the detection efficiency, sensitivity and rapidity, the reaction temperature and amplification time were selected as $38{ }^{\circ} \mathrm{C}$ and $20 \mathrm{~min}$, respectively, for all subsequent experiments. Under the optimized conditions, the PKD-RPA assay results demonstrated that the designed primers (30 $\mathrm{pmol} /$ reaction each) and probe (10 pmol/reaction) can amplify the target $T$. bryosalmonae DNA, while, no test

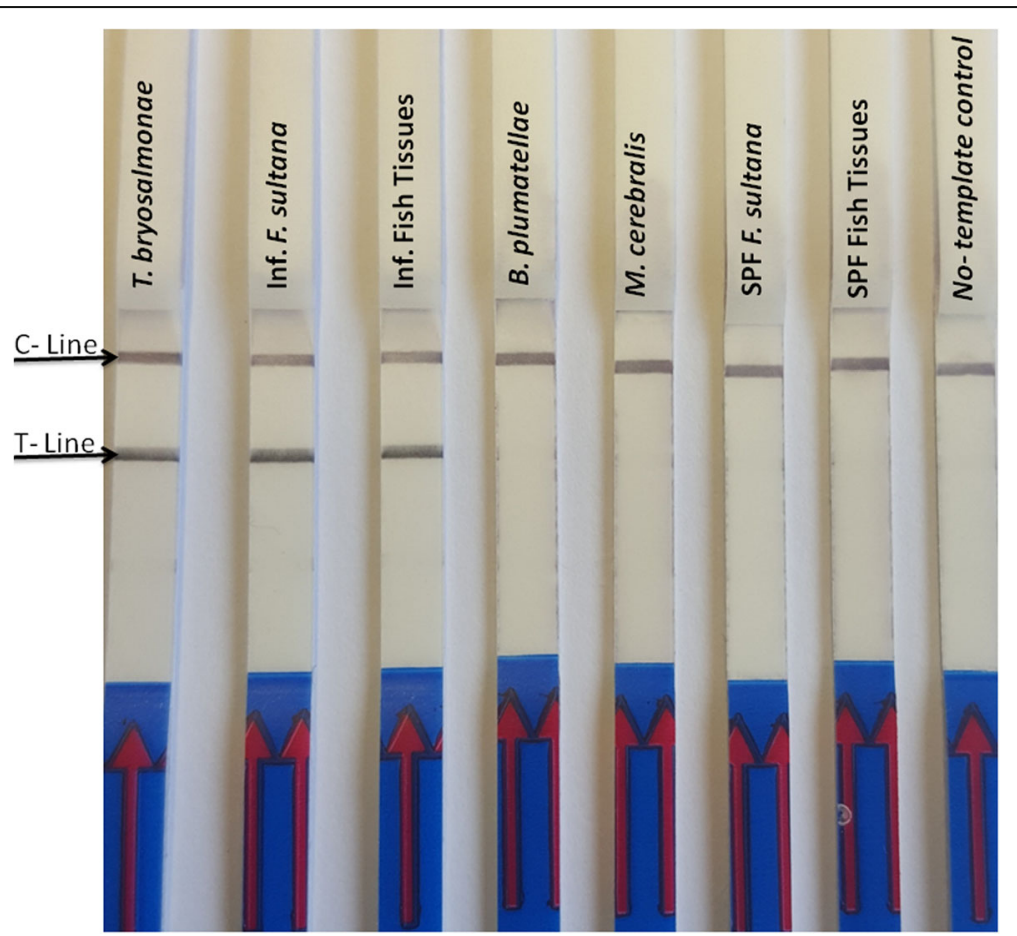

Fig. 2 Specificity of the PKD-RPA assay. Specific amplification of T. bryosalmonae DNA only is indicated by a color signal on both control and test lines for T. bryosalmonae positive samples only, and not with other tested DNA (which show only one color signal, on the control line). C-line: control signal; T-line: location of T. bryosalmonae amplicon; Lane T. bryosalmonae: DNA from pure Tetracapsuloides bryosalmonae mature spore sacs; Lane Inf. F. sultana, DNA from T. bryosalmonae infected Fredericella sultana colonies; Lane Inf. fish tissues: DNA from T. bryosalmonae infected fish kidney; Lane B. plumatellae: DNA from confirmed Buddenbrockia plumatellae sample; Lane M. cerebralis: DNA from Myxobolus cerebralis spores. Lane SPF F. sultana: DNA from specific pathogen-free Fredericella sultana colonies; Lane SPF fish tissues: DNA from specific pathogen-free fish kidney; Lane No-template control: DNA was omitted from the reaction 
bands were observed on the LFD when no-template control was used (Fig. 1).

\section{Specificity and sensitivity of the PKD-RPA assay}

The evaluation of the specificity of the PKD-RPA assay revealed that no cross-reaction or false positive signals were observed with any of the other tested DNA samples (Fig. 2). Furthermore, in silico analysis of the primer and probe set designed for the PKD-RPA assay indicated $100 \%$ identity to the ITS1 sequences of T. bryosalmonae with $100 \%$ query coverage.

The PKD-RPA assay had a lower detection limit of 100 fg for T. bryosalmonae DNA in the presence or absence of genomic DNA of the host, which is 10-times more sensitive than that of the conventional PCR assay (Fig. 3).

\section{Applicability of the PKD-RPA assay}

The applicability of the PKD-RPA assay in detection of $T$. bryosalmonae DNA was evaluated using DNA from 86 clinical fish samples against the conventional diagnostic assay as a reference. The PKD-RPA assay accurately

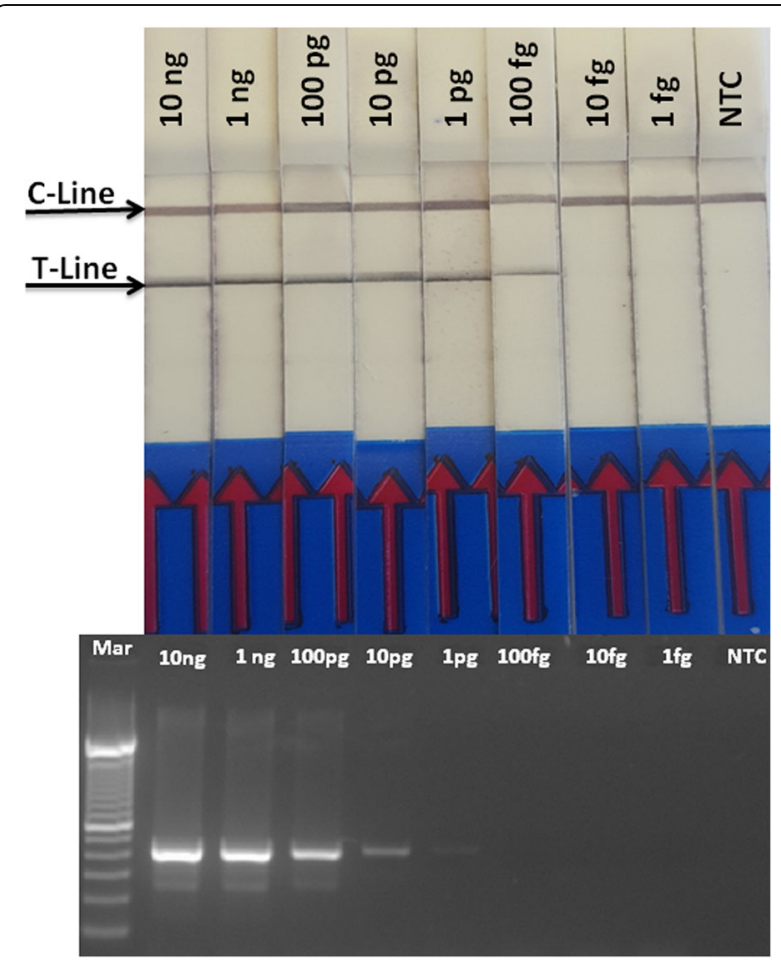

Fig. 3 Sensitivity of the PKD-RPA assay compared with the PCR assay. The figure shows the lower detection limit of the developed PKD-RPA assay compared with the diagnostic PCR assay. Ten-fold serial dilutions of pure DNA from T. bryosalmonae spore sac (10 ng) was used for this purpose. The PKD-PCR and PKD-RPA assays could detect down to $1 \mathrm{pg}$ and $100 \mathrm{fg}$ of T. bryosalmonae DNA, respectively, which is indicated by the presence of a PCR band at $435 \mathrm{bp}$ and the presence of two color signals on the LFD, respectively. C-line: control signal; T-line: location of PK -amplicon; Lane Mar: 100 bp DNA ladder (Invitrogen); Lane NTC: No-template control detected T. bryosalmonae DNA in the samples that had previously tested positive by PCR assay (38 samples); however, no obvious test bands could be observed on the LFD for the remaining samples (48 samples) that had previously tested negative by PCR assay, with no false positive or negative.

\section{Discussion}

Tetracapsuloides bryosalmonae was detected in wild fish species throughout Europe [16, 18-21, 43, 55]. Generally, most of the microbial detection methods are based on PCR and real-time PCRs. Despite their several advantages, these techniques (PCR and real-time PCR) have drawbacks that severely limit their suitability for pointof-use detection and have led to the development of alternative amplification methods [44, 45]. Currently, isothermal amplification methods have been developed to overcome these drawbacks and their features greatly simplify the implementation of these methods in pointof-use diagnosis [45]. Hence, we developed the current assay on the basis of the RPA technique for the rapid, specific, isothermal detection of T. bryosalmonae DNA in fish tissues. The first step in the development of a nucleic acid-based detection assay is to identify and obtain the target sequence [56]. The ITSs are associated with the rRNA gene, which lie between the small subunit ribosomal RNA and the large subunit ribosomal RNA coding regions [57]. ITSs are highly variable and, therefore, may be used for species differentiation [58] or even for isolate differentiation among some parasites [59]. This is the same gene (rRNA) target that is used in the PKD-PCR assay and thus provided a measure of direct comparison between PCR and PKD-RPA assay sensitivity. The PKD-RPA primers were 30 and $34 \mathrm{bp}$, which is approximately the minimum length required by the recombinase protein for the incorporation of oligonucleotides into duplex DNA [46]. We designed the PKD-RPA primers to generate only a short amplicon (141 bp) that would be produced in a relatively shorter time, thus improving the speed of the assay [60]. The use of an LFD for the detection of amplification products increases the specificity of test results and further decreases the total time for the RPA assay [61]. The high degree of LFD specificity was attributed to the use of gold-labeled antiFAM antibodies to specifically capture RPA products, which were detected by a colorimetric signal [62]. The colorimetric signal can be detected by the naked eye, which not only saves time but also eliminates the need for any other post-amplification detection protocol and trained personnel to interpret the results [63].

We selected $38{ }^{\circ} \mathrm{C}$ for $20 \mathrm{~min}$ as the optimum amplification conditions for enzyme performance and speed, without reducing the sensitivity of the assay. Knowing that the assay can perform well outside these values 
makes it robust and flexible and promotes the more successful application of the RPA diagnostic test [64].

The results have demonstrated that the analytical sensitivity of the PKD-RPA assay was 10-times more sensitive than that of a diagnostic PCR developed by Kent et al. [36] and 10-times less sensitive than the real-time PCR assay developed by Fontes et al. [43] (data not shown). Furthermore, compared with PCR and real-time PCR, RPA has some fundamental advantages, such as the ability to function in the presence of several known PCR inhibitors $[65,66]$. In addition, the crowding agent in the RPA formulation, high molecular weight polyethylene glycol, enhances the enzyme catalytic activity and improves sensitivity, efficiency, and specificity of the reaction [67-70]. Moreover, the PKD-RPA assay can be performed much faster $(25 \mathrm{~min})$ than the PKD-PCR assay and post-amplification analysis $(4 \mathrm{~h})$. The current cost of the RPA (reaction and detection) is approximately $€ 5$ per test, which is quite high compared with other molecular detection assays. However, prices are likely to decrease in the future while availability and throughput will increase.

RPA can specifically detect DNA in a shorter time than any other nucleic acid detection methods and is tolerant to impure samples [63]. The diagnostic validation of the PKD-RPA assay with the 86 clinical samples revealed $100 \%$ specificity and sensitivity. Accordingly, PKD-RPA is considered an accurate and rapid assay for field screening and mass monitoring of PKD in fish.

\section{Conclusions}

We developed a novel PKD-RPA assay for the detection of $T$. bryosalmonae that offers considerable advantages including rapidity, sensitivity, specificity and visual detection. These advantages make PKD-RPA a promising assay for the field monitoring of PKD in salmonids.

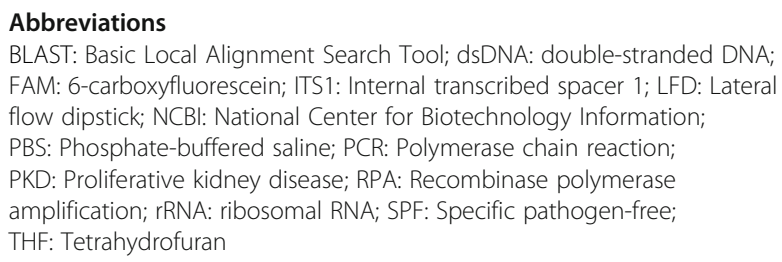

Acknowledgements

Not applicable.

\section{Funding}

This study was funded by the Austrian Science Fund (FWF) Project No. (P 30981- B32).

\section{Availability of data and materials}

All data generated or analyzed during this study are included in this published article.

\section{Authors' contributions}

HS, GK and ME designed the experiments. HS carried out the experiments, analyzed data. HS and GK wrote the manuscript. ME coordinated the study. All authors read and approved the final manuscript.
Ethics approval and consent to participate

Not applicable.

\section{Consent for publication}

Not applicable.

\section{Competing interests}

The authors declare that they have no competing interests.

\section{Publisher's Note}

Springer Nature remains neutral with regard to jurisdictional claims in published maps and institutional affiliations.

Received: 20 December 2017 Accepted: 28 March 2018

Published online: 11 April 2018

\section{References}

1. Hedrick RP, MacDonnell E, de Kinkelin P. Proliferative kidney disease of salmonid fish. Annu Rev Fish Dis. 1993;3:277-90.

2. El-Matbouli M, Hoffmann RW. Influence of water quality on the outbreak of proliferative kidney disease - field studies and exposure experiments. J Fish Dis. 2002;25:459-67.

3. Canning EU, Curry A, Feist S, Longshaw M, Okamura B. Tetracapsula bryosalmonae n. sp. for PKX organism, the cause of PKD in salmonid fish. Bull Eur Assoc Fish Pathol. 1999;19:203-6.

4. Morris DJ, Adams A. Proliferative, presaccular stages of Tetracapsuloides bryosalmonae (Myxozoa: Malacosporea) within the invertebrate host Fredericella sultana (Bryozoa: Phylactolaemata). J Parasitol. 2006;92:984-9.

5. Grabner DS, El-Matbouli M. Transmission of Tetracapsuloides bryosalmonae (Myxozoa: Malacosporea) to Fredericella sultana (Bryozoa: Phylactolaemata) by various fish species. Dis Aquat Org. 2008;79:133-9.

6. Okamura B, Hartikainen H, Schmidt-Posthaus H, Wahli T. Life cycle complexity, environmental change and the emerging status of salmonid proliferative kidney disease. Freshwater Biol. 2011;56:735-53.

7. Feist SW, Longshaw M, Canning EU, Okamura B. Induction of proliferative kidney disease (PKD) in rainbow trout Oncorhynchus mykiss via the bryozoan Fredericella sultana infected with Tetracapsula bryosalmonae. Dis Aquat Org. 2001;45:61-8

8. Grabner DS, El-Matbouli M. Tetracapsuloides bryosalmonae (Myxozoa: Malacosporea) portal of entry into the fish host. Dis Aquat Org. 2010;90: 197-206.

9. Kent ML, Hedrick RP. Development of the PKX myxosporean in rainbow trout Salmo gairdneri. Dis Aquat Org. 1985;1:169-82.

10. Wahli T, Knuesel R, Bernet D, Segner H, Pugovkin D, Burkhardt-Holm P, et al. Proliferative kidney disease in Switzerland: current state of knowledge. J Fish Dis. 2002:25:491-500.

11. Tops S, Lockwood W, Okamura B. Temperature-driven proliferation of Tetracapsuloides bryosalmonae in bryozoan hosts portends salmonid declines. Dis Aquat Org. 2006;70:227-36.

12. Bettge $K$, Wahli T, Segner H, Schmidt-Posthaus H. Proliferative kidney disease in rainbow trout: time- and temperature-related renal pathology and parasite distribution. Dis Aquat Org. 2009;83:67-76.

13. Clifton-Hadley RS, Richards RH, Bucke D. Proliferative kidney disease (PKD) in rainbow trout Salmo gairdneri: further observations on the effects of water temperature. Aquaculture. 1986;55:165-71.

14. Ferguson HW, Ball HJ. Epidemiological aspects of proliferative kidney disease among rainbow trout Salmo gairdneri Richardson in Northern Ireland. J Fish Dis. 1979;2:219-25.

15. Feist SW, Bucke D. Proliferative kidney disease in wild salmonids. Fish Res. 1993; 17:51-8.

16. Wahli T, Bernet D, Pascale April Steiner PA, Schmidt-Posthaus H. Geographic distribution of Tetracapsuloides bryosalmonae infected fish in Swiss rivers: an update. Aquat Sci. 2007;69:3-10.

17. Sterud E, Forseth T, Ugedal O, Poppe TT, Jorgensen A, Bruheim T, et al. Severe mortality in wild Atlantic salmon Salmo salar due to proliferative kidney disease (PKD) caused by Tetracapsuloides bryosalmonae (Myxozoa). Dis Aquat Org. 2007;77:191-8.

18. Skovgaard A, Buchmann K. Tetracapsuloides bryosalmonae and PKD in juvenile wild salmonids in Denmark. Dis Aquat Org. 2012;101:33-42.

19. Jenčič V, Zajc U, Kušar D, Ocepek M, Pate M. A survey on Tetracapsuloides bryosalmonae infections in Slovene freshwaters. J Fish Dis. 2014;37:711-7. 
20. Mo TA, Jørgensen A. A survey of the distribution of the PKD-parasite Tetracapsuloides bryosalmonae (Cnidaria: Myxozoa: Malacosporea) in salmonids in Norwegian rivers - additional information gleaned from formerly collected fish. J Fish Dis. 2017:40:621-7.

21. Vasemägi A, Nousiainen I, Saura A, Vähä J, Valjus J, Huusko A. First record of proliferative kidney disease agent Tetracapsuloides bryosalmonae in wild brown trout and European grayling in Finland. Dis Aquat Org. 2017;125:73-8.

22. Abd-Elfattah A, Fontes I, Kumar G, Soliman H, Hartikainen H, Okamura O, et al. Vertical transmission of Tetracapsuloides bryosalmonae (Myxozoa), the causative agent of salmonid proliferative kidney disease. Parasitology. 2014; 141:482-90.

23. Abd-Elfattah A, El-Matbouli M, Kumar G. Structural integrity and viability of Fredericella sultana statoblasts infected with Tetracapsuloides bryosalmonae (Myxozoa) under diverse treatment conditions. Vet Res. 2017;48:19.

24. Gorgoglione B, Kotob MH, El-Matbouli M. Migrating zooids allow the dispersal of Fredericella sultana (Bryozoa) to escape from unfavourable conditions and further spreading of Tetracapsuloides bryosalmonae. $J$ Invertebr Pathol. 2016;140:97-102.

25. Henderson M, Okamura B. The phylogeography of salmonid proliferative kidney disease in Europe and North America. Proc R Soc Lond B Biol Sci. 2004;271:1729-36.

26. Klontz GW, Chacko AJ. Methods to detect the organism causing proliferative kidney disease in salmonids. Bull Eur Assoc Fish Pathol. 1983;3:33-6.

27. Castagnaro M, Marin de Mateo M, Ghittino C, Hedrick RP. Lectin histochemistry and ultrastructure of rainbow trout, Oncorhynchus mykiss, kidney affected by proliferative kidney disease. Dis Aquat Org. 1991;10:173-83.

28. Hedrick RP, Marin M, Castagnaro M, Monge D, de Kinkelin P. The rapid lectinbased staining procedure for the detection of the myxosporeans causing proliferative kidney disease in salmonid fish. Dis Aquat Org. 1992;13:129-32.

29. Smith CE, Morrison JK, Ramsey HW, Ferguson HW. Proliferative kidney disease (PKD): first reported outbreak in North America. J Fish Dis. 1984;7:207-16.

30. Ellis AE, Mcvicar AH, Munro ALS. Proliferative kidney disease in brown trout, Salmo trutta L., and Atlantic salmon, Salmo salar L., parr: histological and epidemiological observations. J Fish Dis. 1985;8:197-208.

31. Clifton-Hadley RS, Bucke D, Richards RH. A study of the sequential clinical and pathological changes during proliferative kidney disease in rainbow trout, Salmo gairdneri. J Fish Dis. 1987;10:335-52.

32. Adams AR, Richards H, Marin de Mateo M. Development of monoclonal antibodies to PKX the causative agent of PKD. J Fish Dis. 1992;15:515-21.

33. Marin de Mateo M, Adams A, Richards RH, Castagnaro M, Hedrick RP. Monoclonal antibody and lectin probes recognize developmental and sporogonic stages of PKX, the causative agent of proliferative kidney disease in European and North American salmonid fish. Dis Aquat Org. 1993:15:23-9.

34. Marin de Mateo M, McGeorge J, Morris D, Kent ML. Comparative studies of PKX and Sphaerospora spp. from salmonids using lectin and monoclonal antibody staining techniques. J Fish Dis. 1996;19:55-63.

35. Saulinier D, De Kinkelin P. Polymerase chain reaction primers for investigations on the causative agent of proliferative kidney disease of salmonids. J Fish Dis. 1997;20:467-70

36. Kent ML, Khattra J, Hervio DM, Devlin RH. Ribosomal DNA sequence analysis of isolates of the PKX myxosporean and their relationship to members of the genus Sphaerospora. J Aquat Anim Health. 1998;10:12-21.

37. Morris DJ, Adams A, Richards RH. In situ hybridization of DNA probes to PKX, the causative organism of proliferative kidney disease. J Fish Dis. 1999; 22:161-3.

38. Morris DJ, Adams A, Richards RH. In situ hybridization identifies the gill as a portal of entry for PKX (Phylum Myxozoa), the causative agent of proliferative kidney disease in salmonids. Parasitol Res. 2000;86:950-6.

39. Morris DC, Morris DJ, Adams A. Development of improved PCR to prevent false positives and false negatives in the detection of Tetracapsula bryosalmonae, the causative agent of proliferative kidney disease. J Fish Dis. 2002;25:483-90.

40. Hedrick RP, Baxa DV, De Kinkelin P, Okamura B. Malacosporean-like spores in urine of rainbow trout react with antibody and DNA probes to Tetracapsuloides bryosalmonae. Parasitol Res. 2004;92:81-8.

41. El-Matbouli M, Soliman H. Rapid diagnosis of Tetracapsuloides bryosalmonae, the causative agent of proliferative kidney disease (PKD) in salmonid fish by a novel DNA amplification method, loop-mediated isothermal amplification (LAMP). Parasitol Res. 2005;96:277-84.

42. Grabner DS, El-Matbouli M. Comparison of the susceptibility of brown trout (Salmo trutta) and four rainbow trout (Oncorhynchus mykiss) strains to the myxozoan Tetracapsuloides bryosalmonae, the causative agent of proliferative kidney disease (PKD). Vet Parasitol. 2009;165:200-6.

43. Fontes I, Hartikainen H, Holland JW, Secombes CJ, Okamura B. Tetracapsuloides bryosalmonae abundance in river water. Dis Aquat Org. 2017;124:145-57.

44. Asiello PJ, Baeumner AJ. Miniaturized isothermal nucleic acid amplification, a review. Lab Chip. 2011;11:1420-30.

45. Kim J, Easley CJ. Isothermal DNA amplification in bioanalysis: strategies and applications. Bioanalysis. 2011;3:227-39.

46. Piepenburg O, Williams C, Stemple D, Armes N. DNA detection using recombination proteins. PLoS Biol. 2006;4:e204.

47. Hoff M. DNA amplification and detection made simple (Relatively). PLoS Biol. 2006;4:e222.

48. Shibata T, Cunningham RP, DasGupta C, Radding CM. Homologous pairing in genetic recombination: complexes of recA protein and DNA. Proc Natl Acad Sci USA. 1979:76:5100-4.

49. Formosa T, Alberts BM. Purification and characterization of the T4 bacteriophage uvsX protein. J Biol Chem. 1986:261:6107-18.

50. West SC. Molecular views of recombination proteins and their control. Nat Rev Mol Cell Biol. 2003:4:435-45.

51. Dzantiev BB, Byzova NA, Urusov AE, Zherdev AV. Immunochromatographic methods in food analysis. Trends Analyt Chem. 2014;55:81-93.

52. Wu YD, Zhou DH, Zhang LX, Zheng WB, Ma JG, Wang M, et al. Recombinase polymerase amplification (RPA) combined with lateral flow (LF) strip for equipment-free detection of Cryptosporidium spp. oocysts in dairy cattle feces. Parasitol Res. 2016;115:3551-5.

53. Kumar G, Abd-Elfattah A, Soliman H, El-Matbouli M. Establishment of medium for laboratory cultivation and maintenance of Fredericella sultana for in vivo experiments with Tetracapsuloides bryosalmonae (Myxozoa). J Fish Dis. 2013;36:81-8.

54. Kumar G, Abd-Elfattah A, El-Matbouli M. Differential modulation of host genes in the kidney of brown trout Salmo trutta during sporogenesis of Tetracapsuloides bryosalmonae (Myxozoa). Vet Res. 2014;45:101.

55. Dash M, Vasemägi A. Proliferative kidney disease (PKD) agent Tetracapsuloides bryosalmonae in brown trout populations in Estonia. Dis Aquat Org. 2014;109:139-48.

56. Weiss JB. DNA probes and PCR for diagnosis of parasitic infections. Clin Microbiol Rev. 1995:8:113-30.

57. Froeschke $\mathrm{G}$, von der Heyden S. A review of molecular approaches for investigating patterns of coevolution in marine host-parasite relationships. Adv Parasitol. 2014;84:209-52.

58. Dávila AM, Momen H. Internal-transcribed-spacer (ITS) sequences used to explore phylogenetic relationships within Leishmania. Ann Trop Med Parasitol. 2000;94:651-4.

59. Som I, Azam A, Bhattacharya A, Bhattacharya S. Inter- and intra-strain variation in the $5.8 \mathrm{~S}$ ribosomal RNA and internal transcribed spacer sequences of Entamoeba histolytica and comparison with Entamoeba dispar, Entamoeba moshkovskii and Entamoeba invadens. Int J Parasitol. 2000;30:723-8.

60. Head SR, Komori HK, LaMere SA, Whisenant T, Van Nieuwerburgh F, Salomon DR, et al. Library construction for next-generation sequencing: overviews and challenges. Biotechniques. 2014;56:61.

61. Posthuma-Trumpie GA, Korf J, van Amerongen A. Lateral flow (immuno) assay: its strengths, weaknesses, opportunities and threats. A literature survey. Anal Bioanal Chem. 2009;393:569-82.

62. Jaroenram W, Owens L. Recombinase polymerase amplification combined with a lateral flow dipstick for discriminating between infectious Penaeus stylirostris densovirus and virus-related sequences in shrimp genome. J Virol Methods. 2014;208:144-51

63. Sun $K$, Xing W, Yu X, Fu W, Wang Y, Zou M, et al. Recombinase polymerase amplification combined with a lateral flow dipstick for rapid and visual detection of Schistosoma japonicum. Parasit Vectors. 2016;9:476.

64. Prescott MA, Reed AN, Jin L. Rapid detection of Cyprinid herpesvirus 3 in latently infected koi by recombinase polymerase amplification. J Aquat Anim Health. 2016:28:173-80

65. Kersting S, Rausch V, Bier F, von Nickisch-Rosenegk M. Rapid detection of Plasmodium falciparum with isothermal recombinase polymerase amplification and lateral flow analysis. Malar J. 2014;13:99.

66. Rohrman B, Richards-Kortum R. Inhibition of recombinase polymerase amplification by background DNA: a lateral flow-based method for enriching target DNA. Anal Chem. 2015;87:1963-7.

67. Minton AP. The effect of volume occupancy upon the thermodynamic activity of proteins: some biochemical consequences. Mol Cell Biochem. 1983;55:119-40. 
68. Zimmerman SB, Harrison B. Macromolecular crowding increases binding of DNA polymerase to DNA: an adaptive effect. Proc Natl Acad Sci USA. 1987; 84:1871-5.

69. Sasaki Y, Miyoshi D, Sugimoto N. Effect of molecular crowding on DNA polymerase activity. Biotechnol J. 2006;1:440-6.

70. Lareu RR, Harve KS, Raghunath M. Emulating a crowded intracellular environment in vitro dramatically improves RT-PCR performance. Biochem Biophys Res Commun. 2007;363:171-7.

Submit your next manuscript to BioMed Central and we will help you at every step:

- We accept pre-submission inquiries

- Our selector tool helps you to find the most relevant journal

- We provide round the clock customer support

- Convenient online submission

- Thorough peer review

- Inclusion in PubMed and all major indexing services

- Maximum visibility for your research

Submit your manuscript at www.biomedcentral.com/submit 